\title{
PENGARUH PERSEPSI KEBERMANFAATAN, PERSEPSI KEMUDAHAN PENGGUNAAN, DAN KEPUASAN WAJIB PAJAK TERHADAP PENGGUNAAN \\ E-FILING BAGI WAJIB PAJAK \\ DI YOGYAKARTA
}

Nurul Citra Noviandini

FAKULTAS EKONOMI

UNIVERSITAS NEGERI YOGYAKARTA

\begin{abstract}
ABSTRAK
Penelitian ini bertujuan untuk mengetahui (1) Pengaruh Persepsi Kebermanfaatan terhadap Penggunaan e- Filing, (2) Pengaruh Persepsi Kemudahan Penggunaan terhadap Penggunaan eFiling, (3) Pengaruh Kepuasan Wajib Pajak terhadap Penggunaan e-Filing, dan (4) Pengaruh Persepsi Kebermanfaatan, Persepsi Kemudahan, dan Kepuasan Wajib Pajak secara bersama-sama terhadap Penggunaan e-Filing.

Penelitian ini merupakan penelitian asosiatif dengan pendekatan survai yang dilakukan di Kantor Direktorat Jendral Pajak Yogyakarta. Responden yang digunakan adalah wajib pajak badan yang menggunakan e-Filing yang berjumlah 99 perusahaan. Teknik pengambilan data menggunakan kuesioner/angket. Sebelum dilakukan analisis data terlebih dahulu dilakukan uji coba instrumen, semua item pertanyaan yang digunakan valid dan semua variabel reliabel. Teknik analisis data menggunakan (1) Uji Asumsi Klasik dan (2) Uji Hipotesis yang terdiri dari uji regresi linier sederhana dan uji regresi linier berganda.

Hasil penelitian menunjukkan bahwa (1) Terdapat pengaruh positif Persepsi Kebermanfaatan terhadap

Penggunaan e-Filing ditunjukkan dengan koefisien regresi variabel yang menunjukkan angka positif

Penggunaan e-Filing ditunjukkan dengan koefisien regresi variabel yang menunjukkan angka positif $(0,340)$ dan mempunyai signifikansi 0,000 (di bawah 0,05), (3) Terdapat pengaruh positif Kepuasan Wajib Pajak terhadap Penggunaan e-Filing ditunjukkan dengan koefisien regresi variabel yang menunjukkan angka positif $(0,130)$ dan mempunyai signifikansi 0,011 (di bawah 0,05), (4) Terdapat pengaruh positif Persepsi Kebermanfaatan, Persepsi Kemudahan, dan Kepuasan Wajib Pajak secara bersama-sama terhadap Penggunaan eFiling ditunjukkan dengan koefisien regresi semua yang menunjukkan angka positif. Dengan Sumbangan Relatif (SR) yang diberikan oleh X1 adalah sebesar $7 \%$, X2 adalah sebesar $73 \%$, dan X3 adalah sebesar $20 \%$, dengan total sumbangan efektif (SE) sebesar 36,7\%. Nilai koefisien determinasi (Adjusted $\mathrm{R}^{2}$ ) sebesar 0,342 atau 34,2\% yang berarti bahwa Penggunaan e-Filing yang dapat dijelaskan oleh variabel Persepsi Kebermanfaatan, Persepsi Kemudahan, dan Kepuasan Wajib Pajak adalah sebesar $34,2 \%$.

Kata Kunci : e-Filing, Persepsi Kebermanfaatan, Persepsi Kemudahan Penggunaan, Kepuasan Wajib Pajak, Wajib Pajak Badan.
\end{abstract} $(0,122)$ dan mempunyai signifikansi 0,021 (di bawah 0,05), (2) Terdapat pengaruh positif Persepsi Kemudahan Penggunaan terhadap 


\section{Jurnal Nominal / Volume I Nomor I / Tahun 2012}

\section{A. PENDAHULUAN}

Teknologi internet memberikan pengaruh yang cukup besar terhadap perkembangan informasi dunia.

Dahulu memerlukan waktu yang cukup lama untuk mendapatkan informasi mengenai kejadian yang terjadi hari ini. Namun sekarang informasi dapat menyebar dengan cepat. Hanya dibutuhkan waktu satu detik saja untuk mendapatkan informasi dari internet. Saat ini, informasi menjadi kunci terpenting dalam kehidupan manusia. Serupa dengan perkembangan teknologi informasi, penerimaan pajak menjadi sumber pendapatan negara yang semakin hari semakin penting. Pajak merupakan salah satu sumber penerimaan negara terbesar. Penerimaan pajak ini sangat berperan dalam kesejahteraan masyarakat di Indonesia.

Dan seiring dengan hal tersebut maka berbagai usaha telah dilakukan oleh segenap aparat Direktorat Jenderal Pajak dalam meningkatkan penerimaan pajak dari Wajib Pajak dengan cara melakukan pembahar uan- pembaharuan dalam sistem perpajakan. Pembaharuan dalam sistem perpajakan ini ditandai dengan penerapan teknologi informasi terkini dalam pelayanan perpajakan. Peningkatan pelayanan perpajakan ini terlihat dengan dikembangkannya administrasi perpajakan modern dan teknologi informasi di berbagai aspek kegiatan. Perubahan mendasar yang berkaitan dengan modernisasi pajak terjadi di awal tahun 2005 yaitu dilaksanakannya jenis pelayanan kepada Wajib Pajak yang baru dalam rangka penyampaian surat pemberitahuan dan penyampaian perpanjangan surat pemberitahuan tahunan menggunakan elektronik (e- filing).

Dengan adanya sistem ini, para Wajib Pajak akan lebih mudah menunaikan kewajibannya tanpa harus mengantri di Kantor-kantor Pelayanan Pajak sehingga dirasa lebih efektif dan efisien. Selain itu, pengiriman data Surat Pemberitahuan (SPT) dapat dilakukan dimana saja dan kapan saja baik di dalam maupun di luar negeri, tidak tergantung pada jam kantor dan dapat pula dilakukan di hari libur dan tanpa kehadiran Petugas Pajak (24 jam dalam 7 hari), di mana data akan dikirim langsung ke database Direktorat Jenderal Pajak dengan fasilitas internet yang disalurkan melalui satu atau beberapa Perusahaan Penyedia Jasa Aplikasi (ASP). Dan penggunaan e-filing dapat mengurangi beban proses administrasi laporan pajak menggunakan kertas.

Dengan adanya kemudahan untuk memenuhi kewajiban perpajakan diharapkan dapat meningkatkan kepatuhan Wajib Pajak. Selain itu, transisi cara penyampaian dan pelaporan Surat Pemberitahuan (SPT) dapat memudahkan dan memberi manfaat bagi Direktorat Jenderal Pajak (DJP) sendiri dalam pengelolaan pajak. Oleh karena itu perlu dukungan semua pihak secara terus-menerus agar peningkatan pelayanan kepada wajib pajak terus berjalan dan sekaligus terciptanya administrasi perpajakan yang modern. Namun saat ini belum semua Wajib Pajak menggunakan e-filing karena Wajib Pajak masih menganggap bahwa penggunaan sistem komputer dalam pelaporan SPT sangat membingungkan dan menyulitkan. Hal ini dikarenakan masih banyak Wajib P ajak yang belum paham tentang pengoperasian e-Filing dan kemampuan wajib pajak untuk menggunakan e-Filing masih minim. Selain itu, sosialisasi tentang e-Filing kepada Wajib Pajak mesih belum maksimal dan berkelanjutan. Padahal pelaporan SPT secara komputerisasi memiliki manfaat yang lebih besar bagi 


\section{Jurnal Nominal / Volume I Nomor I / Tahun 2012}

Wajib Pajak maupun Direktorat Jenderal Pajak (DJP). Selain kemampuan wajib pajak, adanya perbedaan persepsi mengenai kebermanfaatan, persepsi mengenai kemudahan penggunaan dan kepuasan pengguna terhadap e-Filing juga menjadi penentu sistem ini dapat diterima atau tidak.

\section{B. PEMBAHASAN}

E-filing adalah suatu cara penyampaian SPT atau penyampaian Pemberitahuan Perpanjangan SPT Tahunan secara elektronik yang dilakukan secara on-line yang realtime melalui website Direktorat Jenderal Pajak (www.pajak.go.id ) atau Penyedia Jasa Aplikasi atau Application Service Provider (ASP). Sehingga Wajib Pajak (WP) tidak perlu lagi melakukan pencetakan semua formulir laporan dan menunggu tanda terima secara manual. Online berarti bahwa Wajib Pajak dapat melaporkan pajak melalui internet dimana saja dan kapan saja, sedangkan kata realtime berarti bahwa konfirmasi dari Direktorat Jenderal Pajak (DJP) dapat diperoleh saat itu juga apabila data-data Surat Pemberitahuan (SPT) yang diisi dengan lengkap dan benar telah sampai dikirim secara elektronik.

Wajib Pajak tidak perlu lagi datang ke Kantor Pelayanan Pajak jika sudah menggunakan fasilitas efiling sehingga penyampaian SPT menjadi lebih mudah dan cepat. Hal ini karena pengiriman data SPT d apat dilakukan di mana saja dan kapan saja serta dikirim langsung ke database Direktorat Jenderal Pajak dengan fasilitas internet yang disalurkan melalui satu atau beberapa perusahaan Penyedia Jasa Aplikasi (ASP) yang ditunjuk oleh Direktorat Jenderal Pajak. E-filing mempermudah penyampaian SPT dan memberi keyakinan kepada Wajib pajak bahwa SPT itu sudah benar diterima
Direktorat Jenderal Pajak serta keamanan jauh lebih terjamin.

Dan berikut ini merupakan prosedur penggunaan efiling adalah sebagai berikut: (www.klinik- pajak.com)

1. Wajib Pajak menyampaikan Surat Permohonan memperoleh e-FIN atau melaksanakan e-filing kepada Direktorat Jenderal Pajak yaitu kepada Kantor Pelayanan Pajak tempat Wajib Pajak terdaftar atau melalui website Direktorat Jenderal Pajak (www.pajak.go.id).

2. Direktorat Jenderal Pajak via Kantor Pelayanan Pajak memberikan e-FIN

3. Wajib Pajak mendaftar ke Penyedia Jasa Aplikasi (ASP) dan meminta Digital Certificate ke Direktorat Jenderal Pajak melalui Penyedia Jasa Aplikasi (ASP)

4. Direktorat Jenderal Pajak melalui Kantor Pelayanan Pajak memberikan Digital Certificate melalui Penyedia Jasa Aplikasi (ASP)

5. Wajib Pajak melakukan e-filing ke Penyedia Jasa Aplikasi (ASP) yang diteruskan ke Kantor Pelayanan Pajak

6. Direktorat Jenderal Pajak melalui Kantor Pelayanan Pajak memberikan bukti penerimaan e-SPT yang mengandung informasi berupa : NPWP (Nomor Pokok Wajib Pajak), tanggal transaksi, jam transaksi, Nomor Transaksi Penyampaian SPT (NTPS), Nomor Transaksi Pengiriman ASP (NTPA), nama ASP.

7. Wajib Pajak menyampaikan print out dari Penyedia Jasa Aplikasi (ASP) berupa induk SPT yang sudah diberi bukti penerimaan elektronik, ditanda tangani dan dilampiri sesuai ketentuan 


\section{Jurnal Nominal / Volume I Nomor I / Tahun 2012}

Kantor Pelayanan Pajak.

PENGARUH PERSEPSI KEBERMANFAATAN TERHADAP PENGGUNAAN E-FILING

Tabel 1. Hasil Uji Regresi Persepsi Kebermanfaatan Terhadap Penggunaan E-Filing

\begin{tabular}{|l|l|}
\hline Konstanta & 5,808 \\
\hline Koefisien Regresi & 0,122 \\
\hline Sig & 0,021 \\
\hline R & 0,232 \\
\hline R2 & 0,054 \\
\hline
\end{tabular}

Sumber : data primer yang telah diolah

Berdasarkan tabel tersebut dapat diperoleh persamaan regresi sederhana sebagai berikut:

$\mathrm{Y}=5,808+0,122 \mathrm{X} 1$

Persamaan regresi sederhana tersebut mendapatkan konstanta sebesar 5,808. Hasil tersebut

memberikan pengertian bahwa apabila variabel independen bernilai nol, maka perubahan Penggunaan e-Filing menjadi sebesar 5,808 satuan. Koefisien regresi Persepsi Kebermanfaatan sebesar 0,122 bernilai positif hal ini berarti bahwa setiap kenaikan Persepsi Kebermanfaatan sebesar 1 satuan akan menaikkan Penggunaan e-Filing sebesar 0,122 satuan. Nilai sig sebesar 0,021 (di bawah 0,05) mengindikasikan bahwa variabel Persepsi Kebermanfaatan berpengaruh secara signifikan terhadap variabel Penggunaan e-Filing. Hasil uji regresi tersebut mendukung Hipotesis pertama (H1) yang menyatakan terdapat pengaruh positif Persepsi Kebermanfaatan terhadap Penggunaan eFiling bagi Wajib Pajak di Yogyakarta. Hal ini juga dapat dilihat dari nilai korelasi regresi (R) antara Persepsi Kebermanfaatan dan Penggunaan e-Filing sebesar 0,232 (kurang dari
0,5), sehingga dapat dikatakan bahwa korelasi antara Persepsi Kebermanfaatan dan Penggunaan e-Filing lemah. Koefisien determinasi (R Square) sebesar 0,054 menunjukkan bahwa sebesar 5,4\% variabel Penggunaan e-Filing dipengaruhi oleh variabel Persepsi Kebermanfaatan dan sisanya sebesar 94,6\% dipengaruhi oleh variabel lain yang tidak diteliti dalam penelitian ini.

PENGARUH PERSEPSI KEMUDAHAN PENGGUNAAN TERHADAP PENGGUNAAN E -FILING

Tabel 2. Hasil Uji Regresi Persepsi Kemudahan Penggunaan Terhadap Penggunaan E-Filing

\begin{tabular}{|l|l|}
\hline Konstanta & $-3,161$ \\
\hline Koefisien Regresi & 0,340 \\
\hline Sig & 0,000 \\
\hline R & 0,561 \\
\hline R2 & 0,314 \\
\hline
\end{tabular}

Sumber : data primer yang telah diolah

Berdasarkan tabel tersebut dapat diperoleh persamaan regresi sederhana sebagai berikut: $\mathrm{Y}=-3,161$ $+0,340 \times 2$

Persama regresi sederhana tersebut mendapatkan konstanta sebesar -3,161. Hasil tersebut memberikan pengertian bahwa apabila variabel independen bernilai nol, maka perubahan Penggunaan e-Filing menjadi berkurang sebesar 3,161 satuan. Koefisien regresi Persepsi Kemudahan Penggunaan sebesar 0,340 bernilai positif hal ini berarti bahwa setiap kenaikan Persepsi Kebermanfaatan sebesar 1 satuan akan menaikkan Penggunaan e-Filing sebesar 0,340 satuan. Nilai sig sebesar 0,000 (di bawah 0,05) mengindikasikan bahwa variabel Persepsi Kemudahan Penggunaan berpengaruh secara signifikan terhadap variabel Penggunaan e-Filing. Hasil uji 


\section{Jurnal Nominal / Volume I Nomor I / Tahun 2012}

regresi tersebut mendukung Hipotesis kedua (H2) yang menyatakan terdapat pengaruh positif Persepsi Kemudahan Penggunaan terhadap Penggunaan e-Filing bagi Wajib Pajak di Yogyakarta. Hal ini juga dapat dilihat dari nilai korelasi regresi (R) antara Persepsi Kemudahan Penggunaan dan Penggunaan e-Filing sebesar 0,561 (lebih dari 0,5), sehingga dapat dikatakan bahwa korelasi antara Persepsi Kemudahan Penggunaan dan Penggunaan e-Filing kuat. Koefisien determinasi ( $\mathrm{R}$ Square) sebesar 0,314 menunjukkan bahwa sebesar $31,4 \%$ variabel Penggunaan e-Filing dipengaruhi oleh variabel Persepsi Kemudahan Penggunaan dan sisanya sebesar $68,6 \%$ dipengaruhi oleh variabel lain yang tidak diteliti dalam penelitian ini.

PENGARUH KEPUASAN WAJIB PAJAK TERHADAP PENGGUNAAN E-FILING

Tabel 3. Hasil Uji Regresi Kepuasan wajib Pajak Terhadap Penggunaan E-Filing

Persama regresi sederhana tersebut mendapat-

\begin{tabular}{|l|l|}
\hline Konstanta & 6,006 \\
\hline Koefisien Regresi & 0,130 \\
\hline Sig & 0,011 \\
\hline R & 0,254 \\
\hline R2 & 0,065 \\
\hline
\end{tabular}

kan konstanta sebesar 6,006. Hasil tersebut memberikan pengertian bahwa apabila variabel independen bernilai nol, maka perubahan Penggunaan e-Filing menjadi sebesar 6,006 satuan. Koefisien regresi Kepuasan Pengguna sebesar 0,130 bernilai positif hal ini berarti bahwa setiap kenaikan Persepsi Kebermanfaatan sebesar 1 satuan akan menaikkan Penggunaan e-Filing sebesar 0,130 satuan. Nilai sig sebesar 0,011 (di bawah 0,05) mengindikasikan bahwa variabel Kepuasan Pengguna berpengaruh secara signifikan

terhadap variabel Penggunaan e-Filing. Hasil uji regresi tersebut mendukung Hipotesis ketiga (H3) yang menyatakan terdapat pengaruh positif Kepuasan Pengguna terhadap Penggunaan e-Filing bagi Wajib Pajak di Yogyakarta. Hal ini juga dapat dilihat dari nilai korelasi regresi (R) antara Kepuasan Pengguna dan Penggunaan e-Filing sebesar 0,254 (kurang dari 0,5), sehingga dapat dikatakan bahwa korelasi antara Kepuasan Pengguna dan Penggunaan e-Filing kuat. Koefisien determinasi (R Square) sebesar 0,065 menunjukkan bahwa sebesar 6,5\% variabel Penggunaan e-Filing dipengaruhi oleh variabel Kepuasan Pengguna dan sisanya sebesar 93,5\% dipengaruhi oleh variabel lain yang tidak diteliti dalam penelitian ini.

PENGARUH PERSEPSI KEBERMANFAATAN, PERSEPSI KEMUDAHAN PENGGUNAAN DAN KEPUASAN WAJIB

\section{PAJAK TERHADAP PENGGUNAAN E-FILING}

Tabel 4. Hasil Uji Regresi Berganda

\begin{tabular}{|l|l|}
\hline Konstanta & $-7,497$ \\
\hline Koefisien Regresi X1 & 0,031 \\
\hline Koefisien Regresi X2 & 0,326 \\
\hline Koefisien Regresi X3 & 0,095 \\
\hline Sig X1 & 0,532 \\
\hline Sig X2 & 0,000 \\
\hline Sig X3 & 0,047 \\
\hline R & 0,601 \\
\hline R2 & 0,362 \\
\hline
\end{tabular}

Sumber : data primer yang telah diolah

Berdasarkan tabel tersebut dapat diperoleh persamaan regresi sebagai berikut:

$Y=-7,497+0,031 X 1+0,326 X 2+0,095 X 3$

Berdasarkan persamaan regresi tersebut maka dapat dijelaskan kontanta sebesar -7,497, hal ini 


\section{Jurnal Nominal / Volume I Nomor I / Tahun 2012}

menyatakan bahwa jika variabel independen dianggap nol, maka Penggunaan e-Filing adalah berkurang sebesar 7,497 satuan. Koefisien regresi $\mathrm{X} 1$ sebesar 0,031 bernilai positif hal ini berarti bahwa setiap kenaikan Persepsi Kebermanfaatan sebesar 1 satuan akan menaikkan Penggunaan e-Filing sebesar 0,031 satuan jika X2 dan X3 dianggap nol. Koefisien regresi X2 sebesar 0,326 bernilai positif hal ini berarti bahwa setiap kenaikan Persepsi Kemudahan Penggunaan sebesar 1 satuan akan mempengaruhi Penggunaan e-Filing sebesar 0,326 satuan jika X1 dan X3 dianggap nol. Koefisien regresi X3 sebesar 0,095 bernilai positif hal ini berarti bahwa setiap kenaikan Kepuasan Pengguna sebesar 1 satuan akan mempengaruhi Penggunaan eFiling sebesar 0,095 satuan jika X1 dan X2 dianggap nol. Ketiga variabel independen menunjukkan nilai sig dibawah 0,05 mengindikasikan bahwa ketiga variabel independen berpengaruh secara bersama-sama terhadap variabel dependen. Hasil uji regresi tersebut mendukung Hipotesis keempat (H4) yang menyatakan terdapat positif persepsi kebermanfaatan, persepsi kemudahan penggunaan dan kepuasan pengguna secara bersama-sama terhadap penggunaan e-Filing bagi Wajib Pajak di Yogyakarta. Hal ini juga dapat dilihat dari nilai korelasi regresi $(\mathrm{R})$ antara Persepsi Kebermanfaatan, Persepsi Kemudahan Penggunaan, Kepuasan Pengguna dan Penggunaan e-Filing sebesar 0,601 (lebih dari 0,5), sehingga dapat dikatakan bahwa korelasi antara Persepsi Kebermanfaatan, Persepsi Kemudahan Penggunaan, Kepuasan Pengguna dan Penggunaan e-Filing kuat. Koefisien determinasi (R Square) sebesar 0,362 menunjukkan bahwa sebesar 36,2\% variabel Penggunaan e- Filing dipengaruhi oleh variabel Persepsi Kebermanfaatan, Persepsi Kemudahan Penggunaan, dan Kepuasan
Pengguna secara bersama-sama. Dan sisanya sebesar 63,8\% dipengaruhi oleh variabel lain yang tidak diteliti dalam penelitian ini.

\section{PENUTUP}

\section{Kesimpulan}

1. Terdapat pengaruh positif dan signifikan Persepsi Kebermanfaatan terhadap Penggunaan eFiling. Hal ini berarti Persepsi Kebermanfaatan mempengaruhi tingkat Penggunaan e-Filing. Semakin tinggi tingkat Persepsi Kebermanfaatan eFiling, maka wajib pajak akan semakin sering pula menggunakan e-Filing. Koefisien regresi X1 yang menunjukkan angka positif sebesar 0,122 dan mempunyai signifikansi 0,021 (di bawah 0,05) membuktikan hipotesis pertama yang menyebutkan bahwa terdapat pengaruh positif antara variabel Persepsi Kebermanfaatan terhadap Penggunaan eFiling.

2. Terdapat pengaruh positif dan signifikan variabel Persepsi Kemudahan Penggunaan dengan variabel Penggunaan e-Filing. Hal ini berarti Persepsi Kemudahan Penggunaan mempengaruhi tingkat Penggunaan e-Filing. Semakin tinggi tingkat Persepsi Kemudahan Penggunaan, maka wajib pajak akan semakin sering pula menggunakan eFiling. Koefisien regresi X2 yang menunjukkan angka positif sebesar 0,340 dan mempunyai signifikansi 0,000 (di bawah 0,05) membuktikan hipotesis kedua yang menyebutkan bahwa terdapat pengaruh positif antara variabel Persepsi Kemudahan Penggunaan terhadap Penggunaan e- Filing.

3. Terdapat pengaruh positif dan signifikan variabel Kepuasan Pengguna dengan variabel Penggunaan e- Filing. Hal ini berarti Kepuasan 


\section{Jurnal Nominal / Volume I Nomor I / Tahun 2012}

Pengguna mempengaruhi tingkat Penggunaan eFiling. Semakin tinggi tingkat Kepuasan Pengguna, maka wajib pajak akan semakin sering pula menggunakan e-Filing. Koefisien regresi X3 sebesar 0,130 dan mempunyai signifikansi 0,011 (di bawah 0,05) membuktikan hipotesis ketiga yang menyebutkan bahwa terdapat pengaruh positif antara variabel Kepuasan Pengguna terhadap Penggunaan e-Filing.

4. Terdapat pengaruh positif Persepsi Kebermanfaatan, Persepsi Kemudahan Penggunaan dan Kepuasan Pengguna secara bersama-sama terhadap penggunaan e-Filing. Hal ini berarti Kebermanfaatan, Kemudahan dan Kepuasan Pengguna mempengaruhi tingkat Penggunaan e-Filing. Semakin tinggi Kebermanfaatan, Kemudahan dan Kepuasan Pengguna dalam mengoperasikan eFiling maka wajib pajak akan semakin sering menggunakan e-Filing. Berdasarkan hasil perhitungan uji regresi berganda, diperoleh hasil positif pada semua variabel independen terhadap variabel dependen. Hal ini mengindikasikan ada pengaruh positif secara bersama-sama terhadap variabel dependen, didukung level signifikansi semua prediktor yang di bawah 0,005. Nilai koefisien determinasi (Adjusted $\mathrm{R}^{2}$ ) sebesar 0,342 atau 34,2\% yang berarti bahwa Penggunaan e-Filing yang dapat dijelaskan oleh variabel Persepsi Kebermanfaatan, Persepsi Kemudahan Penggunaan, dan Kepuasan Pengguna adalah sebesar $34,2 \%$ sedangkan sisanya sebesar $65,8 \%$ dijelaskan oleh variabel lain yang tidak diteliti pada penelitian ini.

\section{DAFTAR PUSTAKA}

Aditya Fradana. (2011). Pengaruh Kualitas Sistem Informasi, Perceived Ease of Use, dan Perceived
Usefulness

Terhadap Kepuasan Penggunaan Software Akuntansi. Skripsi. Fakultas Ilmu Sosial dan Ekonomi Universitas Negeri Yogyakarta. Yogyakarta.

Ainurrofiq. (2007). Pengaruh Dimensi Kepercayaan (Trust) Terhadap Partisipasi Pelanggan E-Commerce (Studi Pada Pelanggan E-Commerce Di Indonesia). Tesis. Program Pasca Sarjana Fakultas Ekonomi Universitas Brawijaya. Malang.

Azizul Kholis. (2002). Analisis Penerimaan (Acceptance) Penggunaan Personal Computer Dengan Technology Acceptance Model (TAM) (Studi Kasus pada Perusahaan Perdagangan Kecil di Medan). Tesis. Program Pascasarjana Magister Sains Akuntansi Universitas Diponegoro.

Charlesto Sekundera P.L. 2006. Analisis Penerimaan Penggunaan Akhir Dengan Menggunakan Technology Acceptance Model Dan End User Computing Satisfaction Terhadap Penerapan Sistem Core Banking Pada BANK ABC. Tesis. Program Studi Magister Sains Akuntansi. Program Pascasarjana Universitas Diponegoro.

Chin, W. and Todd, P. (1995). "On the Use, Usefulness, and Ease of Use of Structural Equation Modeling in MIS Research: A Note of Caution," Management Information System Quarterly 9, 2, pp. 237-246.

Davis, F.D. (1989). Perceived Usefulness, Perceived Ease of Use, and User Acceptance of Information Technology. MIS Quarterly. Vol. 13 No. 5: pp 319-339.

DeLone,W. and McLean E.R. (2003). "The DeLone and McLean Model of Information System Success: A Ten Year Update.” Journal of MIS (19,:4), 


\section{Jurnal Nominal / Volume I Nomor I / Tahun 2012}

pp 9-30.

Gita Gowinda Kirana. (2010). Analisis Perilaku Penerimaan Wajib Pajak Terhadap Penggunaan EFiling. Skripsi. Fakultas Ekonomi Universitas Diponegoro. Semarang.

Husein Umar. (2001). Riset Akuntansi. Jakarta: Gramedia Pustaka Utama. Imam Ghozali. (2006). Aplikasi Analisis Multivariate dengan Program SPSS. Semarang: Badan Penerbit Universitas Diponegoro.

Istianingsih dan Setyo Hari Wijanto. (2007). Pengaruh Kualitas Sistem Informasi, Perceived Usefulness, Dan Kualitas Informasi Terhadap Kepuasan Pengguna Akhir Software Akuntansi. Kajian Riset Sistem Informasi. Universitas Indonesia.

Joko Sulistyo. 2010. 6 Hari Jago SPSS 17. Yogyakarta : Cakrawala. Jogiyanto. (2005). Sistem Teknologi Informasi Edisi II. Yogyakarta: ANDI.

Livary, Juhani. (2005). An Empirical Test of The DeLone -McLean Model of Information System Success. Database for Advance in Information System (DFA). ISSN: 1532-0936. Volume 36. Proquest Company.

McGill, Tanya, Hobbs, Valerie, \& Klobas, Jane. (2003). "User-Developed Applications and Information Systems Success: a Test of DeLone and McLean's Model'.Information resource Management Journal; Jan-Mar; 16.1.pg.24.

Portal Pajak Indonesia. Penyampaian SPT dan Perpanjangan SPT Tahunan Secara Elektronik. http:// www.klinik- pajak.com/2008/penyampaian-spt-dan -perpanjangan-spt-tahunan-secara-elektronik-efiling.html. Diunduh tanggal 15 Maret 2012.
Risang Hanugara. (2011). Pengaruh Kebermanfaatan dan Kemudahan E-Learning Be Smart Terhadap Penerimaan Pengguna Pada Mahasiswa Akuntansi UNY. Skripsi. Fakultas Ilmu Sosial dan Ekonomi Universitas Negeri Yogyakarta. Yogyakarta.

S. Nasution. (2002). Metode Penelitian Naturalistik -Kualitatif. Bandung: Tarsito.

Seddon, P., B. (1997). A Respecification and Extension of The DeLone and McLean's Model of Information Success. Information System Research, Vol. 8, No. 3.

and Kiew, Min-Yen. (1994). Partial

Test and Development of DeLone and McLean's Model of Information Success.

Sugiyono. (2007). Statistika Untuk Penelitian.Bandung: Alfabeta.

Sutrisno Hadi. (1987). Analisis Regresi. Yogyakarta: Yayasan Penerbitan Universitas Gajah Mada. 